\title{
Thinning effects on biomass and element concentrations of roots in adjacent hornbeam and oak stands in Istanbul, Turkey
}

\author{
Serdar Akburak ${ }^{*}$ (iD and Ender Makineci
}

\begin{abstract}
Background: Thinning is a commonly used treatment in forest management which affects the tree root systems. The effects of thinning on element concentrations and seasonal change of roots were evaluated in adjacent oak (Quercus frainetto Ten.) and hornbeam (Carpinus betulus L.) stands according to the different root diameter classes.

Method: Two replicated control and thinning plots $(50 \mathrm{~m} \times 50 \mathrm{~m}$ ) were set for each species (hornbeam and oak). Thinning treatments (November 2010) reduced 50\% of the basal area in both oak and hornbeam stands. Roots were assessed by seasonal collection over 2 years (from October 2010 to October 2012). The roots were then sorted into diameter classes of $0-2 \mathrm{~mm}$ (fine roots), $2-5 \mathrm{~mm}$ (small roots) and $>5 \mathrm{~mm}$ (coarse roots). C, N, P, K, Ca, Na, Mg, $\mathrm{S}, \mathrm{Mn}, \mathrm{Fe}, \mathrm{Al}, \mathrm{Zn}, \mathrm{Pb}, \mathrm{Ni}, \mathrm{Cu}$ and $\mathrm{Cd}$ were analyzed.

Results: Except coarse roots, the highest root biomasses were determined in April-2011 in all plots. Fine-root biomass in oak was found significantly higher in control plots. In contrast to the oak, the fine-root biomass in the thinned hornbeam plots was higher than in the controls. The small-root biomass did not significantly differ between the thinned and the control plots in both oak and hornbeam stands. However, the coarse-root biomass showed significant differences between the control $\left(1989 \mathrm{~g} \cdot \mathrm{m}^{-2}\right)$ and thinned plots $\left(1060 \mathrm{~g} \cdot \mathrm{m}^{-2}\right)$ in oak, while no difference was detected in hornbeam. The concentrations of $\mathrm{C}, \mathrm{Al}, \mathrm{Pb}, \mathrm{Cd}, \mathrm{Ni}, \mathrm{Zn}, \mathrm{Mn}, \mathrm{Na}, \mathrm{K}, \mathrm{Mg}$ and $\mathrm{P}$ in the fine roots of oak were significantly higher in the thinned plots. However, the concentration of $\mathrm{Pb}, \mathrm{Cd}$ and $\mathrm{Fe}$ in the fine roots was significantly higher in the thinned plots of hornbeam. Significant differences were observed between the species for all elements in the fine roots except for $\mathrm{C}, \mathrm{N}$ and $\mathrm{P}$. In particular, elements in the fine roots tended to increase in July in the oak. In the hornbeam, all element concentrations in the fine roots (except $C, N$, and $S$ ) in the thinned plots showed a tendency to increase in April. The concentrations of $\mathrm{Pb}, \mathrm{Ni}, \mathrm{Al}, \mathrm{Fe}, \mathrm{Cu}, \mathrm{Ca}, \mathrm{Na}, \mathrm{K}, \mathrm{Mg}$ and $\mathrm{P}$ in the hornbeam control plots increased during the April 2011 period.
\end{abstract}

Conclusion: The results indicated that thinning effects on temporal changes and concentrations of elements in the roots could be attributed to species-specific characteristics.

Keywords: Carpinus, Coarse root, Fine root, Quercus, Small root

* Correspondence: sakburak@istanbul.edu.tr

Faculty of Forestry, Soil Science and Ecology Department, Istanbul

University-Cerrahpasa, 34473 Bahcekoy, Sariyer, Istanbul, Turkey

Springer Open (c) The Author(s). 2021 Open Access This article is licensed under a Creative Commons Attribution 4.0 International License, which permits use, sharing, adaptation, distribution and reproduction in any medium or format, as long as you give appropriate credit to the original author(s) and the source, provide a link to the Creative Commons licence, and indicate if changes were made. The images or other third party material in this article are included in the article's Creative Commons licence, unless indicated otherwise in a credit line to the material. If material is not included in the article's Creative Commons licence and your intended use is not permitted by statutory regulation or exceeds the permitted use, you will need to obtain permission directly from the copyright holder. To view a copy of this licence, visit http://creativecommons.org/licenses/by/4.0/. 


\section{Background}

Tree root systems play a vital role in forest ecosystem functions (durability, uptake of water and nutrients, synthesis of various key components including growth regulators, improvement of soil and water infiltration, root canal aeration and prevention of soil erosion) (John et al. 2001; Jose et al. 2004; Thevathasan and Gordon 2004; Jose 2009; Ramachandran Nair et al. 2009). Since a significant proportion of the total biomass in the ecosystem is composed of belowground plant parts, the contribution of the roots in the introduction of nutrients and organic matter into the soil is important for the continuity of the carbon budget and soil fertility (Lehmann and Zech 1998). More than $20 \%$ of total tree biomass is belowground. Tree roots are important in serving all biomass components in many ecosystems (Brunner and Godbold 2007).

Terrestrial ecosystems have been the priority of the scientific world monitoring the response of global change (Yang et al. 2010). However, the accuracy of the nutrient and energy budget for forest ecosystems is limited by the difficulty of obtaining reliable estimates of root production (Eissenstat and Yanai 1997; Vogt et al. 1998). In particular, researches on root dynamics and production play an important role in the impact of environmental degradation on ecosystem processes and in the assessment of net primary production of terrestrial ecosystems (Yang et al. 2010).

Root systems have been divided into a variety of diameter classes (Finér et al. 2011). Generally, roots smaller than $2 \mathrm{~mm}$ are classified as fine roots, those $2-5 \mathrm{~mm}$ as small roots, and larger than $5 \mathrm{~mm}$ as coarse roots (Finér et al. 2011). Fine roots $(<2 \mathrm{~mm})$ are the most active and dynamic part of root systems in terms of carbon storage and absorption of water and nutrients (Akburak et al. 2013).

Roots systems of managed forests may be more susceptible to environmental stresses. Therefore, assessments of roots are needed to evaluate management options while considering sustainability of the ecosystem structure and function (Law and Waring 2015). Forestry treatments such as pruning, prescribed burning, thinning and clear cutting not only affect the amount and quality of element inputs into the soil, but also affect the root systems by breaking the cover and removing biomass, which then changes the microclimatic properties of the soil (Tang et al. 2005; Masyagina et al. 2010). Thinning is a common forestry treatment used around the world to remove suppressed trees and sustain forest stand structure (Kim et al. 2019). Since thinning causes to die of the root systems, the evaluation of root biomass is necessary to accurately estimate the carbon accumulation of the trees (Le Goff and Ottorini 2001). Ryu et al. (2009) found that the amount of fine roots in the thinning plots was lower than in the control. When small roots $(2-5 \mathrm{~mm})$ were assessed, it showed a change similar to the temporal change in the fine roots, but in general, a greater change was exhibited in thinning plots.

Roots may also reflect the response to any anthropogenic stress that directly impacts both the physical and chemical characteristics of the soil. Additional information is also needed on the key physiological and biochemical processes that underpin the cycle of elements in forests and on how forests are affected by management practices (Saunders et al. 2012). Correspondingly, trace element (e.g., A1, Pb, Zn, Mn, etc.) accumulation occurs typically at the root level, even though some plant species do transport these elements to leaves (Kabata-Pendias 2010). Many studies have reported on the temporal element changes and biomass of fine roots (Bakker 1999; Soethe et al. 2007; Yuan and Chen 2010; Kim 2012). Comparatively little, however, has been reported on element stocks and changes in the different root diameter classes. Thinning alters the environmental characteristics of forest ecosystem (Akburak and Makineci 2015; Akburak and Makineci 2016). Plant root systems have important roles in nutrient and water acquisition, element concentrations, plant success and in all ecosystem services and processes. Also, these root functions importantly differ in different root diameters. However, our understanding of these root functions, how they are influenced by environmental changes and how they vary among species is still limited (Freschet and Roumet 2017). The present study aimed to evaluate the effects of thinning treatments on the element concentrations and seasonal change of roots according to the different root classes in oak (Quercus frainetto Ten.) and hornbeam (Carpinus betulus L.) forest stands. The following hypothesis was tested; thinning would have no effect on temporal variations of element concentrations according to different root diameters in oak and hornbeam species.

\section{Materials and methods Study area}

The study was conducted in stands of pure hornbeam (Carpinus betulus L.) and oak (Quercus frainetto Ten.), coppice originated, adjacent and under similar site conditions, in the Education and Research Forest of the Faculty of Forestry at Istanbul University-Cerrahpasa, located in Istanbul Province, Turkey $\left(41^{\circ} 09^{\prime} 15^{\prime \prime}-41^{\circ} 11^{\prime}\right.$ $\left.01^{\prime \prime} \mathrm{N} ; 28^{\circ} 59^{\prime} 17^{\prime \prime}-29^{\circ} 32^{\prime} 25^{\prime \prime} \mathrm{E}\right)$. The research site is at an altitude of $90 \mathrm{~m}$ a.s.l., with a slope of $3 \%-5 \%$, and a west-northwest aspect. Long-term data (1980-2009) indicate a maritime climate with a moderate water deficit in summer. The average annual precipitation is 1111.4 $\mathrm{mm}$ and the mean annual temperature is $12.7^{\circ} \mathrm{C}$. The soil group is Luvisol (IUSS Working Group WRB 2006) 
and loamy clay is the general texture type of the soils (Akburak 2013).

\section{Thinning treatment, root biomass sampling}

For each species (hornbeam and oak) two replicated control and thinning plots $(50 \mathrm{~m} \times 50 \mathrm{~m})$ were set up, and thus, eight sample plots in total were chosen. We determined the stand characteristics including density, mean tree diameter and tree height of the sample plots (Table 1).

Thinning was established by cutting $50 \%$ of the stand basal area at the beginning of November 2010. First sampling was done at the end of October 2010 before thinning treatment, and sequential samplings were confined to the central $25 \mathrm{~m} \times 25 \mathrm{~m}$ area of each plot in order to reduce the negative edge effects (Akburak 2013). Forest floor and ground cover vegetation were manually removed before root sampling. The biomass of the roots was assessed by collecting five samples from 0 to $35 \mathrm{~cm}$ layer using $6.4-\mathrm{cm}$ diameter steel soil corers (Tufekcioglu et al. 2005; Akburak 2013) per plot once every 3 months from October 2010 to October 2012. Over 2 years, 360 root samples in total $(8$ plots $\times 5$ samples from each plot $\times 9$ sampling times) were collected in the study.

\section{Root materials and chemical analysis}

The roots were separated from the soil by soaking in deionized water and then gently washing them over a series of sieves with mesh sizes of 2 and $5 \mathrm{~mm}$, and they were manually sorted. Diameters of long roots over the sieve of $5 \mathrm{~mm}$ mesh size were measured with digital caliper, and they were cut at the segment points of 2.0 and $5.0 \mathrm{~mm}$. Other organic matters were removed from tree roots by color and form. Live and dead roots were not separated and evaluated as total biomass. They were then sorted into root diameter classes of $0-2 \mathrm{~mm}$ (fine roots), $2-5 \mathrm{~mm}$ (small roots) and $>5 \mathrm{~mm}$ (coarse roots). The categorized roots were oven-dried at $65^{\circ} \mathrm{C}$ for $24 \mathrm{~h}$ and then weighed (Tufekcioglu et al. 2006). The samples were ground by grinding mill, and the Dumas dry combustion method was used for the determination of carbon $(\mathrm{C})$ and nitrogen $(\mathrm{N})$ contents using a LECO Truspec $2000 \mathrm{CN}$ analyzer (Akburak 2013).
Sub-samples $(0.5 \mathrm{~g})$ were taken from the roots samples and placed in Teflon tubes after which $4 \mathrm{~mL}$ concentrated $\mathrm{HNO}_{3}$ (nitric acid) and $2 \mathrm{~mL} \mathrm{H}_{2} \mathrm{O}_{2}$ (hydrogen peroxide) were added and the samples were converted into solutions in a microwave digestion system (Berghof Speed Wave) (Çakır and Akburak 2017). The solutions were then prepared with ultra-pure water until the final volume reached $50 \mathrm{~mL}$ and these were stored at $4 .{ }^{\circ} \mathrm{C}$ until analysis. The concentrations of phosphorus $(\mathrm{P})$, potassium (K), calcium $(\mathrm{Ca})$, sodium $(\mathrm{Na})$, magnesium $(\mathrm{Mg})$, manganese $(\mathrm{Mn})$, iron $(\mathrm{Fe})$, aluminum $(\mathrm{Al})$, zinc $(\mathrm{Zn})$, lead $(\mathrm{Pb})$, nickel $(\mathrm{Ni})$, copper $(\mathrm{Cu})$, cadmium $(\mathrm{Cd})$, sulphur $(\mathrm{S})$ in the solutions were determined via ICPOES (Perkin Elmer Optima 7000 DV) spectrometer (Çakır and Akburak 2017). However, certified sample (NIST 1575a pine needles) was also analyzed in order to validate the accuracy of the method and the calibration of the device. The recovery was higher than $96 \%$ for all certified elements.

\section{Statistical analysis}

Weights and element concentrations of the root diameter classes were compared among the plots designated as OT (oak thinned), OC (oak control), HT (hornbeam thinned) and HC (hornbeam control). The KolmogorovSmirnov test was used to determine the distribution of the dataset (Rohlf and Sokal 1980). As a normal distribution could not be achieved by common transformations, the differences between the plots were tested by Kruskal-Wallis analysis (Rohlf and Sokal 1980). The Mann-Whitley $U$ test was used to identify the significant effects (Rohlf and Sokal 1980) of thinning on root element stocks. Differences were considered significant at $p$ $<0.05$. All statistical analyses were performed using IBM-SPSS 20.0 software.

\section{Results}

\section{Effects of thinning on root biomass}

In the mass of fine roots, the differences between species and the differences between thinned and control plots were significant (Table 2). On comparison between thinned and control plots, the small-root mass showed no significant differences in both species. The coarse roots exhibited a significant difference in the oak plots,

Table 1 Stand characteristics of the sample plots

\begin{tabular}{|c|c|c|c|c|}
\hline \multirow[t]{2}{*}{ Parameters } & \multicolumn{2}{|l|}{ Oak } & \multicolumn{2}{|c|}{ Hornbeam } \\
\hline & Control & Thinning & Control & Thinning \\
\hline Density (trees.ha ${ }^{-1}$ ) & 1112 & 592 & 1408 & 702 \\
\hline Basal area $\left(\mathrm{m}^{2} \cdot \mathrm{ha}^{-1}\right)$ & 22.7 & 11.4 & 26.2 & 13.0 \\
\hline Mean tree height $(\mathrm{m})$ & 15.3 & 15.2 & 14.3 & 14.2 \\
\hline Mean tree diameter $(\mathrm{DBH}, \mathrm{cm})$ & 15.8 & 15.3 & 14.9 & 14.7 \\
\hline
\end{tabular}

Taken from Akburak (2013) 


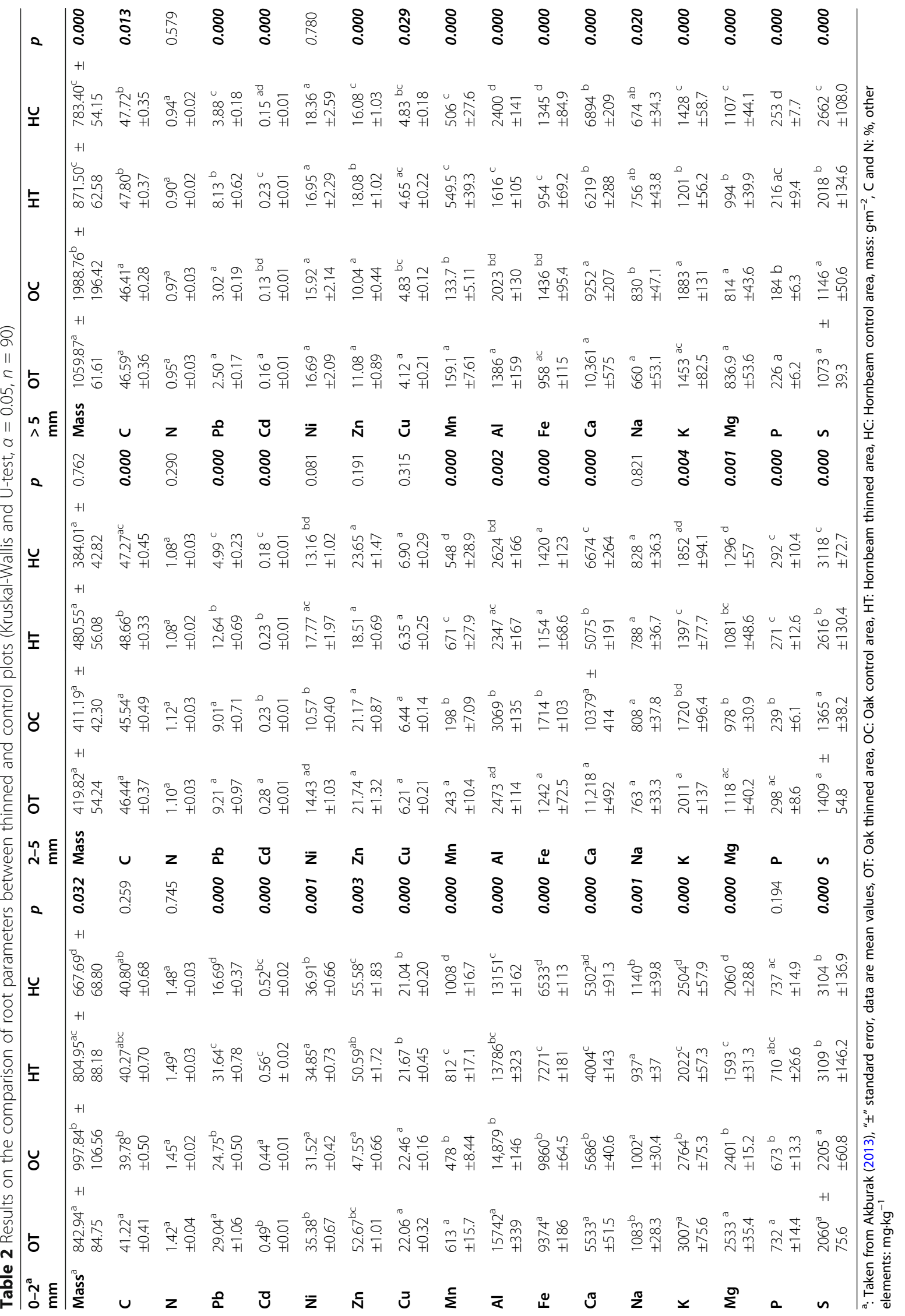


whereas no significant differences were detected in the hornbeam plots. On the other hand, the oak had a significantly greater coarse root mass than the hornbeam (Table 2).

In terms of temporal changes, for the oak plots, the fine-root biomass reached significantly the highest values in April 2011 and was generally higher in the control. The small roots had a temporal tendency similar to that of the fine roots; however, the thinned plots had a greater mass than the control. Moreover, the mass of the coarse roots of the thinned plots had markedly lower values than the control (Fig. 1).

Generally, in the hornbeam plots, the temporal changes in the root masses of the different root classes were similar to those of oak; however, the fine-root mass of the thinned plots had a higher tendency than the control, in contrast to the oak (Fig. 1).
Effects of thinning on fine root element concentrations In the thinned oak plots, concentrations of $\mathrm{C}, \mathrm{Pb}$, $\mathrm{Cd}, \mathrm{Ni}, \mathrm{Zn}, \mathrm{Mn}, \mathrm{Na}$ and $\mathrm{Mg}$ were significantly higher than those of the controls at the rates of $3.6 \%$, $17.3 \%, 11.4 \%, 12.5 \%, 10.8 \%, 28.3 \%, 8.1 \%$ and $4.4 \%$, respectively. On the other hand, concentrations of $\mathrm{Al}$ (5.9\%) and $\mathrm{Fe}(5.5 \%)$ were higher in the control plots (Table 2). Significantly higher concentrations of $\mathrm{Pb}$, $\mathrm{Cd}$ and $\mathrm{Fe}$, with rates of $86.6 \%, 7.7 \%$ and $10.7 \%$, respectively, were found in the thinned hornbeam plots. However, $\mathrm{Ni}, \mathrm{Zn}, \mathrm{Mn}, \mathrm{Ca}, \mathrm{Na}, \mathrm{K}$ and $\mathrm{Mg}$ had higher values in the hornbeam control plots, at the rates of $5.9 \%, 9.9 \%, 24.1 \%, 32.4 \%, 21.7 \%, 23.8 \%$ and $29.3 \%$, respectively (Table 2). Neither oak nor hornbeam showed a significant difference between thinned and control plots for $\mathrm{N}, \mathrm{Cu}$ and $\mathrm{S}$ concentrations (Table 2).
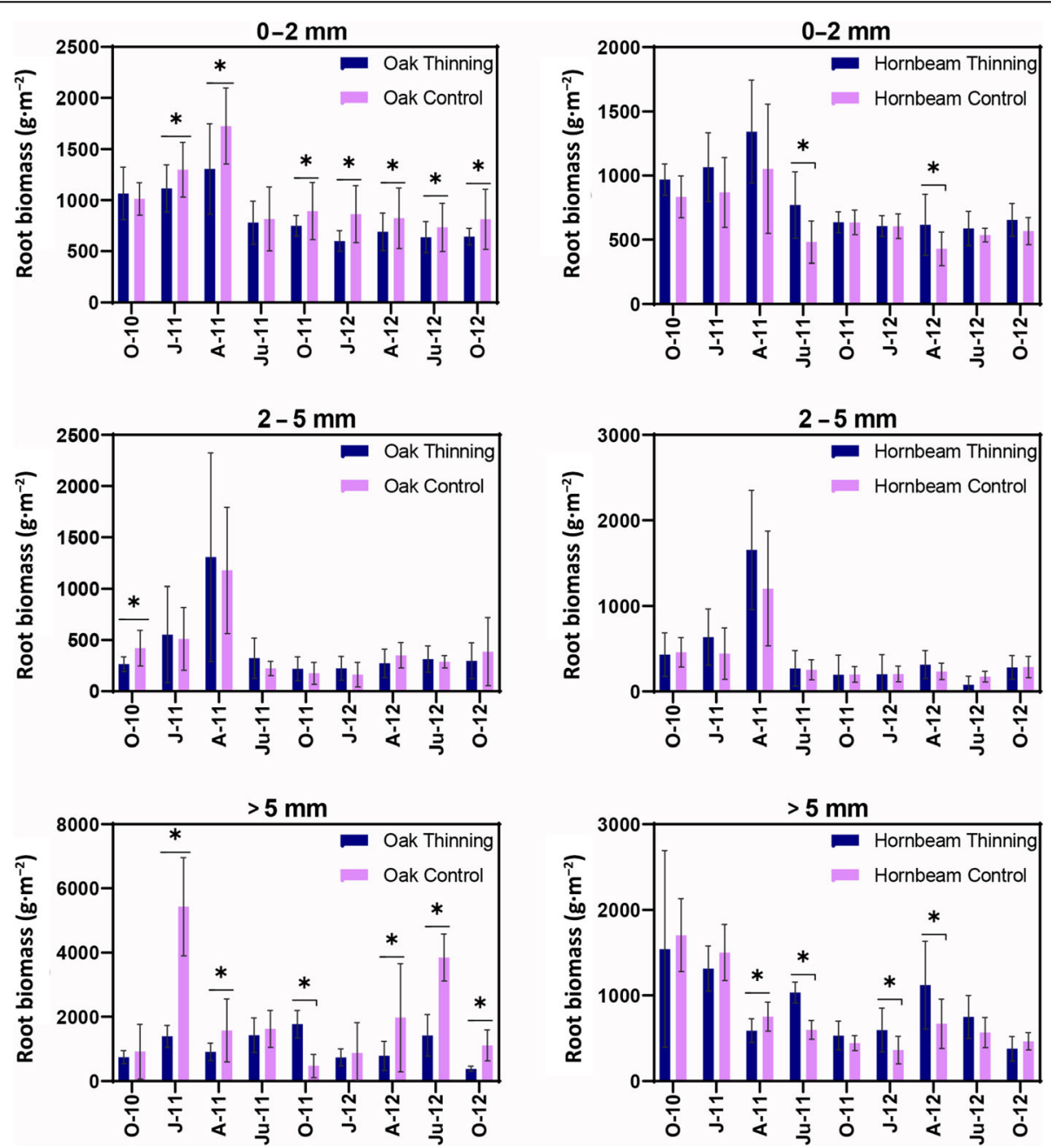

Fig. 1 Seasonal variations of root biomass in different root diameter classes, error bars show standart deviation. "**" shows significant differences between areas. O: October, J: January, A: April, Ju: July 
Significant differences were determined between the species for all elements except $\mathrm{C}, \mathrm{N}$ and $\mathrm{P}$ (Table 2). Regarding temporal changes, $\mathrm{C}, \mathrm{Pb}, \mathrm{Cd}, \mathrm{Ni}, \mathrm{Zn}, \mathrm{Mn}, \mathrm{Na}, \mathrm{K}$, $\mathrm{Mg}$ and $\mathrm{P}$ concentrations in the fine roots of the thinned oak plots fluctuated and were found in higher values than in the controls (Fig. 2). Especially in the thinned oak plots, all elements except $\mathrm{C}, \mathrm{N}, \mathrm{Ni}$ and $\mathrm{Ca}$ reached a peak in July of each year of the research period (Fig. 2). On the other hand, $\mathrm{C}, \mathrm{Ni}, \mathrm{Cu}$ and $\mathrm{Mn}$ concentrations in the oak control plots showed a decreasing trend in July of both 2011 and 2012 (Fig. 2). In addition, $\mathrm{Pb}, \mathrm{Cd}, \mathrm{Al}$, $\mathrm{Fe}, \mathrm{Zn}, \mathrm{Na}, \mathrm{P}$ and $\mathrm{S}$ showed decreases in July 2011 despite an increasing trend in July 2012 (Fig. 2). In the thinned hornbeam plots, all element concentrations except $\mathrm{C}, \mathrm{N}$ and $\mathrm{S}$ had an increasing tendency in April (Fig. 3). In the hornbeam control plots, $\mathrm{Pb}, \mathrm{Ni}, \mathrm{Al}, \mathrm{Fe}$, $\mathrm{Cu}, \mathrm{Ca}, \mathrm{Na}, \mathrm{K}, \mathrm{Mg}$ and $\mathrm{P}$ showed different trends in different years, with an increase in April 2011 and a decrease in April 2012 (Fig. 3), while N, Cd and Mn showed a decreasing tendency in April of both 2011 and 2012 (Fig. 3). In both the thinned and control plots of hornbeam, temporal changes of the elements were generally similar; however, $\mathrm{Pb}$ in the thinned plots and $\mathrm{Mn}$,
$\mathrm{Ca}, \mathrm{Na}, \mathrm{K}$ and $\mathrm{Mg}$ in the control plots exhibited higher values in temporal variation (Fig. 3).

\section{Effects of thinning on small root element concentrations}

The $\mathrm{Cd}, \mathrm{Ni}, \mathrm{Mn}, \mathrm{K}, \mathrm{Mg}$ and $\mathrm{P}$ concentrations of the small roots in the thinned oak plots were significantly higher than in the control plots, whereas $\mathrm{Al}$ and $\mathrm{Fe}$ were higher in the control (Table 2). The thinned hornbeam plots had significantly higher $\mathrm{C}, \mathrm{Pb}, \mathrm{Cd}, \mathrm{Ni}$ and $\mathrm{Mn}$ concentrations; however, the $\mathrm{Al}, \mathrm{Ca}, \mathrm{K}, \mathrm{Mg}$ and $\mathrm{S}$ concentrations were significantly lower than those of the controls (Table 2).

Regarding temporal changes, $\mathrm{N}, \mathrm{Pb}, \mathrm{Cd}, \mathrm{Zn}, \mathrm{Cu}, \mathrm{Ca}$, $\mathrm{Mg}, \mathrm{P}, \mathrm{S}, \mathrm{Fe}$ and $\mathrm{Al}$ concentrations in the small roots of the thinned oak plots increased in July 2011, but decreased in July 2012 (Fig. 2). In contrast, the elements N, $\mathrm{Pb}, \mathrm{Cd}, \mathrm{Zn}, \mathrm{P}, \mathrm{Mg}, \mathrm{K}$ and $\mathrm{S}$ in the oak control plots decreased in July of both 2011 and 2012 (Fig. 2). Moreover, the elements $\mathrm{Cd}, \mathrm{Ni}, \mathrm{Zn}, \mathrm{Cu}, \mathrm{K}, \mathrm{Mg}$ and $\mathrm{Ca}$ in the oak control plots showed a temporal decreasing trend (Fig. 2). The $\mathrm{Pb}, \mathrm{Cd}, \mathrm{Al}, \mathrm{Zn}, \mathrm{Cu}, \mathrm{Mn}, \mathrm{Ca}, \mathrm{Mg}$ and $\mathrm{P}$ in the thinned hornbeam plots, in addition to the elements $\mathrm{C}$, $\mathrm{Ni}, \mathrm{Zn}, \mathrm{Al}, \mathrm{Na}, \mathrm{Mg}, \mathrm{P}$ and $\mathrm{K}$ in the hornbeam control

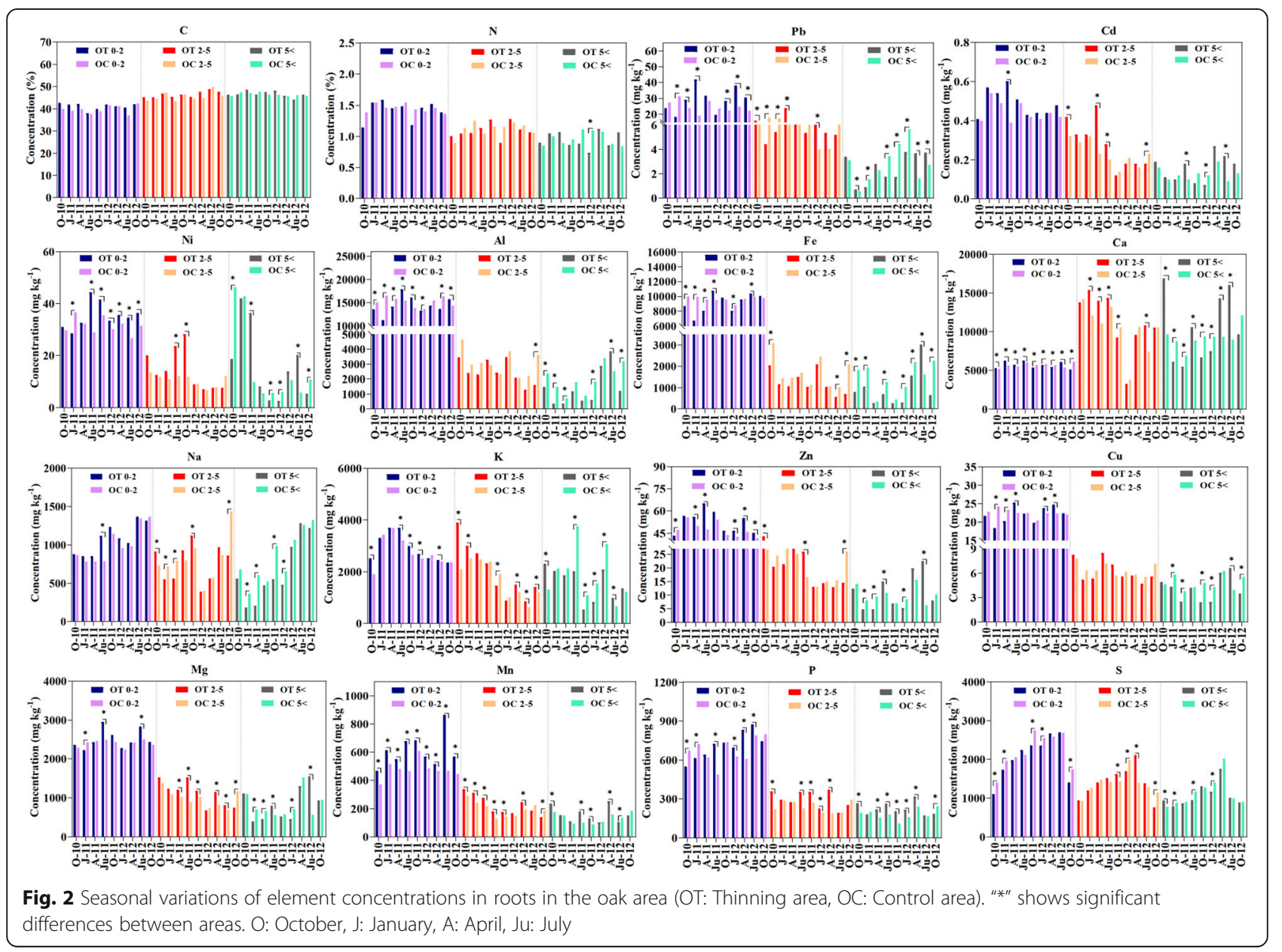




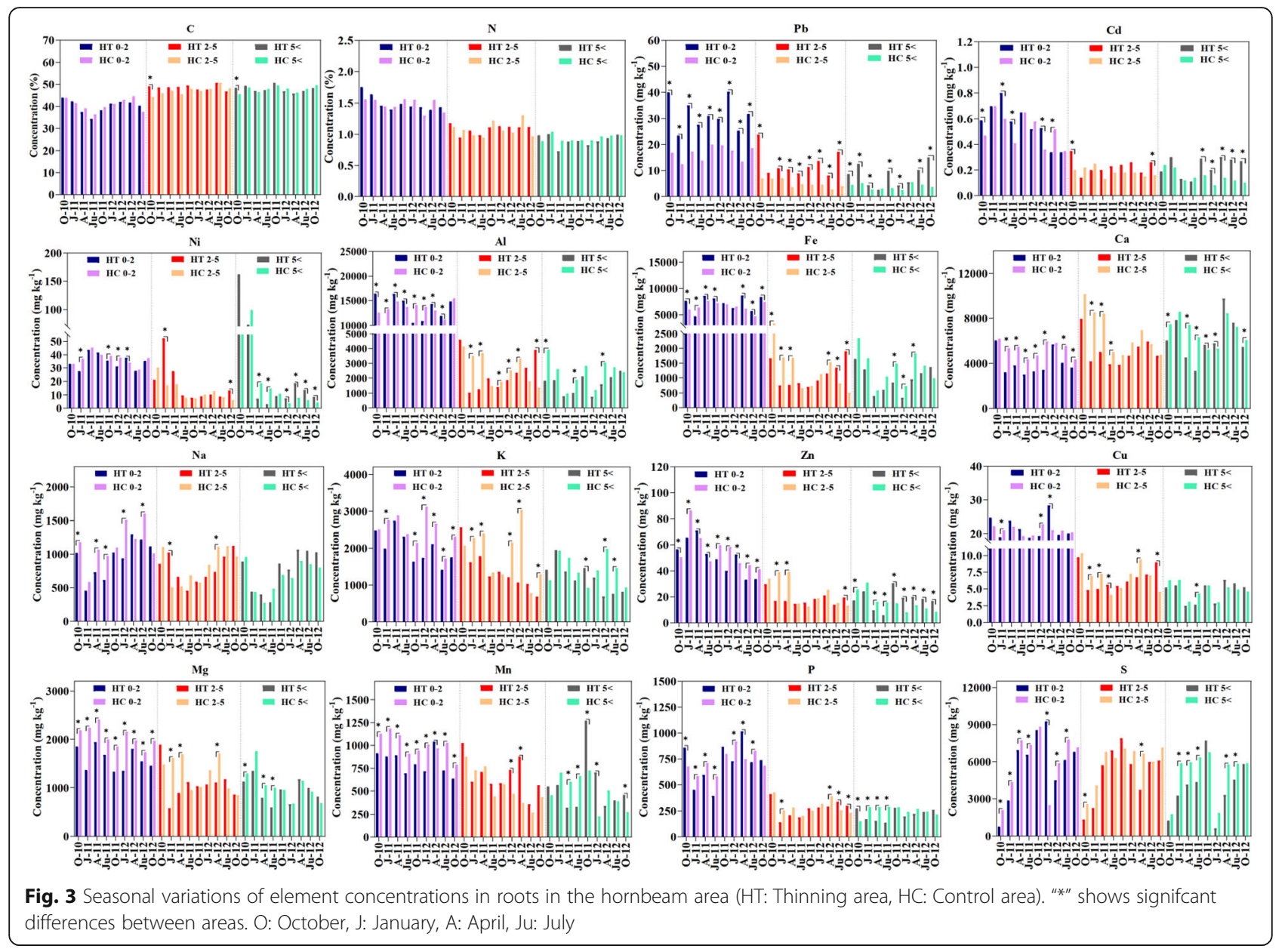

plots showed a distinct increase in April (Fig. 3). Regarding temporal variation, $\mathrm{Pb}, \mathrm{Ni}, \mathrm{Fe}, \mathrm{Mn}$ and $\mathrm{Ca}$ showed a decreasing tendency, even though $\mathrm{C}$ had an increasing trend in the hornbeam control plots (Fig. 3).

Effects of thinning on coarse root element concentrations The $\mathrm{Cd}, \mathrm{Mn}$ and P concentrations of the coarse roots in the thinned oak plots were significantly higher than those of the controls; however, $\mathrm{Cu}, \mathrm{Al}, \mathrm{Fe}, \mathrm{Na}$, and $\mathrm{K}$ concentrations were significantly higher in the control plots (Table 2). The $\mathrm{Pb}, \mathrm{Cd}$, and $\mathrm{Zn}$ were significantly higher in the thinned hornbeam plots despite the higher $\mathrm{Al}, \mathrm{Fe}, \mathrm{K}, \mathrm{Mg}, \mathrm{P}$ and $\mathrm{S}$ in the controls (Table 2 ). As for temporal change, $\mathrm{Al}, \mathrm{Fe}, \mathrm{Zn}, \mathrm{Cu}, \mathrm{Ca}$, and $\mathrm{Mg}$ increased in July in the thinned oak plots (Fig. 2). The $\mathrm{N}, \mathrm{Pb}, \mathrm{Al}, \mathrm{Fe}, \mathrm{Zn}, \mathrm{Cu}, \mathrm{Mn}, \mathrm{Ca}, \mathrm{K}, \mathrm{P}$ and $\mathrm{S}$ in the oak control plots showed increases in July 2011 and April 2012 (Fig. 2). In the temporal evaluation of the hornbeam plots, $\mathrm{N}, \mathrm{Pb}, \mathrm{Cd}, \mathrm{Al}, \mathrm{Fe}, \mathrm{Cu}, \mathrm{Na}, \mathrm{Mg}, \mathrm{P}$ and $\mathrm{S}$ in both thinned and control plots showed an important increase in October of the first year and in April of the second year (Fig. 3).

\section{Discussion}

Root biomass

Root systems are very important component for forest ecosystems regarding annual increase and accumulation of biomass (Kurz 1989; Le Goff and Ottorini 2001). The fine-root biomass in the oak plots reached the highest value in April 2011, and the root biomass of the control plots was significantly higher than that of the thinned plots. Similar to the results of the present study, Ryu et al. (2009) found that the size of the fine-root mass of the thinned plots was significantly lower than that of the control plots. This can suggest that the trees remaining after thinning treatment originated from coppice sprouts have old root systems as stated by Cotillas et al. (2016) and likely with many dead roots. However, as a limitation of this study, we did not compare and determine the live and dead roots within the limited dates to support this suggestion. In contrast to the oak plots, the fine-root biomass of the thinned hornbeam plots was significantly greater than that of the controls. In addition, Hwang et al. (2007) reported higher fine-root biomass in thinned plots. This can be a result of reduced water and nutrient competition after thinning, which 
can stimulate fine root production, depending on the physiological process of the trees remaining after thinning (Da-Lun et al. 2010). There were not significant differences in the biomass of small roots between the thinned and control plots for either hornbeam or oak. However, Tufekcioglu et al. (2005) reported that small root-biomass was greater in control plots than in thinned plots in a beech forest. Coarse roots showed species-specific results, with significant differences between the thinned and control plots in oak, while no significant results were observed in hornbeam. This finding can be explained, as mentioned above, the oak plots had older root systems (Rodríguez-Calcerrada et al. 2011) and thus, they might have had a higher rate of dead roots. Temporal change of fine and small root biomass reached the highest values during the rainy seasons. This was likely because the rainy season is conducive to the use of water and nutrients, and also because temperature conditions are favorable for vegetative plant growth (John et al. 2001).

\section{Concentration of elements}

Element concentrations of different tree fractions are hypervariable and concentrations tend to be higher in the actively growing parts of trees such as leaves, the cambium and fine roots (Hellsten et al. 2013; Iivonen et al. 2006). Concentrations of $\mathrm{C}, \mathrm{Al}, \mathrm{Pb}, \mathrm{Cd}, \mathrm{Ni}, \mathrm{Zn}, \mathrm{Mn}, \mathrm{Na}$, $\mathrm{K}, \mathrm{Mg}$ and $\mathrm{P}$ were higher in the thinned oak plots, whereas $\mathrm{Ca}$ and $\mathrm{Fe}$ were higher in the oak control plots. However, $\mathrm{Pb}$, and $\mathrm{Fe}$ were higher in the hornbeam control plots. All elements (except $\mathrm{C}, \mathrm{N}$ and $\mathrm{P}$ ) showed significant differences between species. Many previous studies in the literature have reported higher concentrations of heavy metals, especially in the fine roots (Yin et al. 1991; Vogt et al. 1993; Bakker 1999; Zhao et al. 2016). Especially higher $\mathrm{Al}$ concentrations were determined in the fine roots in the thinned oak and hornbeam plots. The $\mathrm{Al}$ accumulation take places in the cell walls and plasma membranes through the substitution of $\mathrm{Al}$ in place of $\mathrm{Ca}$ and $\mathrm{Mg}$ in the roots (Kinraide 2003). In addition, $\mathrm{Al}$ is strongly absorbed by roots in a variety of processes or in the formation of insoluble organo-Al complexes (Taylor 1991; Vanguelova et al. 2007). Vanguelova et al. (2005) found that the $\mathrm{Al}$ accumulation in roots could be increased under changing soil condition (water, soil acidity, etc.). In our study, the $\mathrm{Al}$ higher concentrations in the thinned plots may be due to changing soil conditions by thinning treatments. In the present study, all elements except $\mathrm{C}$ and $\mathrm{Ca}$ generally showed a decreasing tendency, depending on root diameter. An especially increasing trend of $\mathrm{Ca}$ can be expressed because of the important role of $\mathrm{Ca}$ on the formation of new cell walls of roots, which increases with the increment of the root diameter. Meier et al. (1985) determined more $\mathrm{P}$ concentrations in fine roots than in coarse roots. In other similar studies, some authors such as Fogel and Hunt (1983) and Lemma et al. (2007); reported more concentrations of $\mathrm{P}, \mathrm{K}, \mathrm{Mg}$ and $\mathrm{S}$ in fine roots. In a temporal comparison, $\mathrm{C}, \mathrm{Pb}, \mathrm{Cd}, \mathrm{Ni}, \mathrm{Zn}, \mathrm{Mn}$, $\mathrm{Na}, \mathrm{K}, \mathrm{Mg}$ and $\mathrm{P}$ in the fine roots were found in higher concentrations in the thinned oak plots than in the control plots. On the other hand, in the thinned hornbeam plots, the $\mathrm{Pb}$ concentration of fine roots was temporally higher in the control plots. Vogt et al. (1993) noted that amount of nutrients and trace elements could be altered under anthropogenic stress conditions. Thus, this situation in the thinned plots could be attributed to soil properties (temperature, water, $\mathrm{pH}$, etc.) changing by thinning treatment (Akburak and Makineci 2015, 2016). In addition, the higher element concentrations of roots in the thinned plots were likely caused by greater root growth, element uptake and translocation after the root competition was reduced with the thinning treatment. Similar to the present study, Yin et al. (1991) reported that $\mathrm{Ca}, \mathrm{Mg}, \mathrm{K}, \mathrm{S}$ and $\mathrm{P}$ showed significant temporal changes and ascribed the possible causes to the dynamic interactions of processes such as root growth, absorption of elements, accumulation in tissues and translocation.

The elements of roots in July in both investigated years (except for small roots in second year) showed a significantly increasing tendency in the thinned oak plots. In contrast, the increasing tendency of elements in roots in the thinned hornbeam plots was in April (except for coarse roots in the first year). This can be explained by the accumulation of elements in the cell walls due to the immobilization of elements in the aboveground organs, although the root activities of the removed trees continued. In addition, temporal changes of elements may have arisen from a variety of ecological conditions (soil temperature, soil moisture, etc.), depending on thinning effects and genetic characteristics (Yin et al. 1991). Moreover, the start of the growing period of a tree species can be species-specific. Similarly, Matula et al. (2012) reported more vegetative growth in hornbeam compared to sessile oak. Thus, element contents of fine and small roots showed a decreasing tendency in July in the control plots, while the element contents of the coarse roots tended to increase. In the hornbeam control plots, element contents of the fine roots decreased in April, while the small and coarse roots tended to increase. This was explained by Kabata-Pendias (2010), who stated that some tree species can accumulate heavy metals, especially in the roots, despite carrying them to the leaves.

\section{Conclusion}

In conclusion, thinning had a specific effect on the fine roots of coppice-originated oak species, likely resulting in root growth and element absorption and translocation 
interactions dependent on the decreasing root competition post treatment. Although the hornbeam species was of coppice origin, there were no clear effects of thinning. This situation demonstrated that, due to long-term coppice forest management (periodical clear-cuttings) in the same site, the roots of the two species of coppice origin developed different responses to the changing site conditions through thinning treatment. Thus, temporal changes of elements in the roots increased in July in oak and in April in hornbeam, depending on both speciesspecific characteristics and changing ecological conditions (soil temperature, soil moisture, etc.) after thinning. The $\mathrm{Al}$ and $\mathrm{Fe}$ contents of the roots were higher than many other elements which are significantly effective on plant growth. This can be interpreted that roots are an important agent for $\mathrm{Al}$ and $\mathrm{Fe}$ cycling in the belowground element cycle. Overall, obtained results remarkably indicated the significant effects of thinning on the temporal changes of element concentrations in roots and species specific changes in forest nutrition management. Further studies are recommended on the dynamic of roots presenting the restoration capability of different tree species to achieve the clear conclusions on the effectiveness of thinning in sustainable forest management. Also, the studies on integrating different forestry treatments (different thinning levels such as $25 \%$ or $75 \%$, clear-cutting, prescribed fire, etc.) will contribute to the understanding of chemical interactions in the belowground biomass.

\section{Abbreviations}

OT: Oak thinned; OC: Oak control; HT: Hornbeam thinned; HC: Hornbeam control; $\mathrm{HNO}_{3}$ : Nitric acid; $\mathrm{H}_{2} \mathrm{O}_{2}$ : Hydrogen peroxide; $\mathrm{C}$ : Carbon; $\mathrm{N}$ : Nitrogen; P: Phosphorus; K: Potassium; Ca: Calcium; Na: Sodium; Mg: Magnesium; Mn: Manganese; Fe: Iron; Al: Aluminum; Zn: Zinc; Pb: Lead; Ni: Nickel; Cu: Copper; Cd: Cadmium; S: Sulphur

\section{Acknowledgements}

This work was supported by Scientific Research Projects Coordination Unit of Istanbul University-Cerrahpasa (Project No. FYD-2016-20102). The authors thank to four anonymous reviewers and editors for their insightful comments and suggestions.

\section{Authors' contributions}

All authors conducted the field experiment, planned and carried out the measurements, developed the theory and analytical methods, run the data analysis and discussed the results. All authors also helped to write, read and approved the final manuscript.

\section{Funding}

This work was supported by Scientific Research Projects Coordination Unit of Istanbul University-Cerrahpasa (Project No. FYD-2016-20102).

\section{Availability of data and materials}

The datasets used during the current study are available from the corresponding author on reasonable request.

\section{Ethics approval and consent to participate}

The subject has no ethic risk.

\section{Consent for publication}

Not applicable.

\section{Competing interests}

The authors declare that they have no competing interests.

Received: 16 June 2020 Accepted: 21 December 2020

Published online: 06 January 2021

\section{References}

Akburak S (2013) The effects of thinning on soil respiration and microbial respiration in oak and hornbeam stands. Istanbul University, Dissertation

Akburak S, Makineci E (2015) Effects of thinning on soil respiration and microbial respiration of forest floor and soil in an oak (Quercus frainetto) forest. Soil Res 53:522-530

Akburak S, Makineci E (2016) Thinning effects on soil and microbial respiration in a coppice-originated Carpinus betulus L. stand in Turkey. iForest 9:783

Akburak S, Oral HV, Ozdemir E, Makineci E (2013) Temporal variations of biomass, carbon and nitrogen of roots under different tree species Scand. J For Res 28:8-16

Bakker MR (1999) Fine-root parameters as indicators of sustainability of forest ecosystems. For Ecol Manag 122:7-16

Brunner I, Godbold DL (2007) Tree roots in a changing world. J For Res 12:78-82

Çakır M, Akburak S (2017) Litterfall and nutrients return to soil in pure and mixed stands of oak and beech. J Faculty For Ist Univ 67:185-200

Cotillas M, Espelta JM, Sánchez-Costa E, Sabaté S (2016) Aboveground and belowground biomass allocation patterns in two Mediterranean oaks with contrasting leaf habit: an insight into carbon stock in young oak coppices. Eur J For Res 135:243-252

Da-Lun T, Yuan-Ying P, Wen-De Y, Xi F, Wen-Xing K, Guang-Jun W, Xiao-Yong C (2010) Effects of thinning and litter fall removal on fine root production and soil organic carbon content in Masson pine plantations. Pedosphere 20:486493

Eissenstat D, Yanai RD (1997) The ecology of root lifespan. Adv Ecol Res 27:1-60

Finér L, Ohashi M, Noguchi K, Hirano Y (2011) Factors causing variation in fine root biomass in forest ecosystems. For Ecol Manag 261:265-277

Fogel R, Hunt G (1983) Contribution of mycorrhizae and soil fungi to nutrient cycling in a Douglas-fir ecosystem. Can J For Res 13:219-232

Freschet GT, Roumet C (2017) Sampling roots to capture plant and soil functions. Funct Ecol 31(8):1506-1518

Hellsten S, Helmisaari HS, Melin Y, Skovsgaard JP, Kaakinen S, Kukkola M, Saarsalmi A, Petersson H, Akselsson C (2013) Nutrient concentrations in stumps and coarse roots of Norway spruce, scots pine and silver birch in Sweden, Finland and Denmark. For Ecol Manag 290:40-48

Hwang J, Son Y, Kim C, Yi M-J, Kim Z-S, Lee W-K, Hong S-K (2007) Fine root dynamics in thinned and limed pitch pine and Japanese larch plantations. J Plant Nutr 30:1821-1839

livonen S, Kaakinen S, Jolkkonen A, Vapaavuori E, Linder S (2006) Influence of long-term nutrient optimization on biomass, carbon, and nitrogen acquisition and allocation in Norway spruce. Can J For Res 36:1563-1571

IUSS Working Group WRB (2006) World reference base for soil resources 2006. World soil resources reports 103. FAO, Rome, p 145

John B, Pandey HN, Tripathi RS (2001) Vertical distribution and seasonal changes of fine and coarse root mass in Pinus kesiya Royle ex.Gordon forest of three different ages. Acta Oecol 22:293-300. https://doi.org/10.1016/S1146$609 \times(01) 01118-3$

Jose S (2009) Agroforestry for ecosystem services and environmental benefits: an overview. Agrofor Syst 76:1-10

Jose S, Gillespie A, Pallardy S (2004) Interspecific interactions in temperate agroforestry. Agrofor Syst 61:237-255

Kabata-Pendias A (2010) Trace elements in soil and plants, 4th edn. CRC Press, Boca Raton

Kim C (2012) Biomass and nutrient concentrations of fine roots in a Korean pine plantation and a sawtooth oak stand. For Sci Tech 8:187-191

Kim S, Li G, Han SH, Kim C, Lee S-T, Son Y (2019) Microbial biomass and enzymatic responses to temperate oak and larch forest thinning: influential factors for the site-specific changes. Sci Total Environ 651:2068-2079

Kinraide T (2003) Toxicity factors in acidic forest soils: attempts to evaluate separately the toxic effects of excessive $\mathrm{Al}^{3+}$ and $\mathrm{H}^{+}$and insufficient $\mathrm{Ca}^{2+}$ and $\mathrm{Mg}^{2+}$ upon root elongation. Eur J Soil Sci 54:323-333

Kurz W (1989) Significance of shifts in carbon allocation patterns for long-term site productivity research. FRI Bulletin. Forest Research Institute, New Zealand Forest Service 
Law B, Waring R (2015) Carbon implications of current and future effects of drought, fire and management on Pacific northwest forests. For Ecol Manag 355:4-14

Le Goff N, Ottorini J-M (2001) Root biomass and biomass increment in a beech (Fagus sylvatica L.) stand in North-East France. Ann For Sci 58:1-13

Lehmann J, Zech W (1998) Fine root turnover of irrigated hedgerow intercropping in northern Kenya. Plant Soil 198:19-31

Lemma B, Nilsson I, Kleja DB, Olsson M, Knicker H (2007) Decomposition and substrate quality of leaf litters and fine roots from three exotic plantations and a native forest in the southwestern highlands of Ethiopia. Soil Biol Biochem 39:2317-2328

Masyagina O, Prokushkin S, Koike T (2010) The influence of thinning on the ecological conditions and soil respiration in a larch forest on Hokkaido Island. Euras Soil Sci 43:693-700

Matula R, Svátek M, Kůrová J, Úradníček L, Kadavý J, Kneifl M (2012) The sprouting ability of the main tree species in central European coppices: implications for coppice restoration. Eur J For Res 131:1501-1511

Meier CE, Grier CC, Cole DW (1985) Below- and aboveground N and P use by Abies amabilis stands. Ecology 66:1928-1942

Ramachandran Nair PK, Mohan Kumar B, Nair VD (2009) Agroforestry as a strategy for carbon sequestration. J Plant Nutr Soil Sci 172:10-23

Rodríguez-Calcerrada J, Pérez-Ramos IM, Ourcival J-M, Limousin J-M, Joffre R, Rambal S (2011) Is selective thinning an adequate practice for adapting Quercus ilex coppices to climate change? Ann For Sci 68:575

Rohlf JF, Sokal RR (1980) Biometry: the principles and practice of statistics in biological research. WH Freeman and Company, New York, p 850

Ryu S-R, Concilio A, Chen J, North M, Ma S (2009) Prescribed burning and mechanical thinning effects on belowground conditions and soil respiration in a mixed-conifer forest, California. For Ecol Manag 257:1324-1332

Saunders M, Tobin B, Black K, Gioria M, Nieuwenhuis M, Osborne B (2012) Thinning effects on the net ecosystem carbon exchange of a Sitka spruce forest are temperature-dependent. Agric For Meteorol 157:1-10

Soethe N, Lehmann J, Engels C (2007) Carbon and nutrient stocks in roots of forests at different altitudes in the Ecuadorian Andes. J Trop Ecol 23:319-328

Tang J, Qi Y, Xu M, Misson L, Goldstein AH (2005) Forest thinning and soil respiration in a ponderosa pine plantation in the Sierra Nevada. Tree Physiol 25:57-66

Taylor GJ (1991) Current views of the aluminum stress response: the physiological basis of tolerance. Curr Top Plant Biochem Physiol 10:57-93

Thevathasan N, Gordon A (2004) Ecology of tree intercropping systems in the North temperate region: experiences from southern Ontario, Canada. New Vistas in Agroforestry, pp 257-268

Tufekcioglu A, Bilmiş T, Sağlam B, Küçük M, Altun L, Yılmaz M, Bilgili E (2006) Influence of fire on belowground root biomass and soil respiration dynamics in young brutian pine (Pinus brutia) stands in North-Western Turkey. For Ecol Manag 234:S167

Tufekcioglu A, Guner S, Tilki F (2005) Thinning effects on production, root biomass and some soil properties in a young oriental beech stand in Artvin, Turkey. J Environ Biol 26:91-95

Vanguelova E, Nortcliff S, Moffat A, Kennedy F (2005) Morphology, biomass and nutrient status of fine roots of scots pine (Pinus sy/vestris) as influenced by seasonal fluctuations in soil moisture and soil solution chemistry. Plant Soil 270:233-247

Vanguelova El, Hirano Y, Eldhuset TD, Sas-Paszt L, Bakker MR, Puttsepp U, Brunner I, Lohmus K, Godbold D (2007) Tree fine root Ca/Al molar ratio-indicator of Al and acidity stress. Plant Biosyst 141:460-480

Vogt KA, Publicover DA, Bloomfield J, Perez JM, Vogt DJ, Silver WL (1993) Belowground responses as indicators of environmental change. Environ Exp Bot 33:189-205

Vogt KA, Vogt DJ, Bloomfield J (1998) Analysis of some direct and indirect methods for estimating root biomass and production of forests at an ecosystem level. Plant Soil 200:71-89

Yang L, Wu S, Zhang L (2010) Fine root biomass dynamics and carbon storage along a successional gradient in Changbai Mountains, China. Forestry 83: 379-387

Yin X, Perry JA, Dixon RK (1991) Temporal changes in nutrient concentrations and contents of fine roots in a Quercus forest. For Ecol Manag 44:175-184
Yuan Z, Chen HY (2010) Fine root biomass, production, turnover rates, and nutrient contents in boreal forest ecosystems in relation to species, climate, fertility, and stand age: literature review and meta-analyses. Crit Rev Plant Sci 29:204-221

Zhao N, Yu GR, He NP, Wang QF, Guo D, Zhang XY, Wang RL, Xu ZW, Jiao CC, Li $N N$, Jia YL (2016) Coordinated pattern of multi-element variability in leaves and roots across Chinese forest biomes. Glob Ecol Biogeogr 25:359-367

\section{Submit your manuscript to a SpringerOpen ${ }^{\odot}$ journal and benefit from:}

- Convenient online submission

- Rigorous peer review

- Open access: articles freely available online

- High visibility within the field

- Retaining the copyright to your article

Submit your next manuscript at $\boldsymbol{\nabla}$ springeropen.com 